\title{
Determination of limiting nutrient to Sweetpotato (Ipomoea batatas (L.) growth on Samoa Oxisol using a Nutrient Omission Technique
}

\author{
Taniela Kepa Siose ${ }^{1}$, Mohammed Abdul Kader ${ }^{1,3,4}$ and \\ Anabella B. Tulin ${ }^{1,2}$ \\ ${ }^{\prime}$ Department of Soil Science, School of Agriculture \& Food Technology, University of South \\ Pacific, Alafua Campus, Apia, Samoa and ${ }^{2}$ PhilRootcrops, Visayas State University, Baybay \\ City, Leyte, Philippines, ${ }^{3}$ Department of Soil Science, Bangladesh Agricultural University, \\ Mymensingh 2202, Bangladesh and ${ }^{4}$ School of Veterinary and Life Science, Murdoch \\ University, South Street, WA 6150, Australia
}

\section{ABSTRACT}

This study was conducted to investigate the influence of various macroand micronutrients on the growth and root yield of sweetpotato (variety $\mathrm{IB} / \mathrm{PH} / 03$ ) grown in a Samoan Oxisol under semi-controlled screenhouse conditions. The following nutrient elements were considered: $\mathrm{N}, \mathrm{P}, \mathrm{K}, \mathrm{Mg}, \mathrm{S}$, $\mathrm{B}, \mathrm{Cu}, \mathrm{Fe}, \mathrm{Mo}, \mathrm{Mn}, \mathrm{Ni}$, and $\mathrm{Zn}$. The set-up involved pot nutrient omission trials wherein the twelve nutrient elements were combined to form an ALL treatment with subsequent 12 treatments made by excluding one nutrient consecutively from the ALL combinations. Treatments were arranged in a randomized complete block design with four replications for all treatments while six for the ALL treatment. Results showed that P was the most limiting factor to sweetpotato vegetative growth and root yield. Reduced storage root yield in relation to ALL were also observed when N, P, K, S, B, Fe, Mn, Mo and Ni were not supplied, although the difference was insignificant. Thus unless P deficiency is addressed, the deficiency effects of these nutrients on storage root yield remain insignificant.

Keywords: sweetpotato, Samoan Oxisol, limiting nutrients, nutrient omission technique

\section{INTRODUCTION}

Many tropical soils are less productive because of inherently low fertility, and Oxisol is one of them. Oxisol is a highly weathered soil that is predominantly comprised of kaolinitic and aluminum and iron oxide clays that are principally responsible for the soil's inherent low cation exchange capacity (Vitousek \& Sanford Jr. 1986). Oxisol is also characterized by high soil acidity, aluminium saturation, and high phosphorus fixation capacity (Fageria \& Stone 1999). Its agricultural potential is generally low (Foth 1990, Osman 2013) but can be made productive through appropriate agronomic practices (Sanchez \& Salinas 1991, Osman 2013).

Correspondence: Anabella B. Tulin Address: PhilRootcrops, Visayas State University, Baybay City, Leyte, Philippines 6521-A E-mail: anabella.tulin@vsu.edu.ph

DOI: $10.32945 /$ atr3917.2017 
Diagnosing nutrient deficiency in soils by way of nutrient omission technique is a common method of evaluating soil fertility. The nutrient omission technique is designed to identify which of the assigned nutrient/s that is/are most limiting to plant growth. Sweet corn or maize (Zea mays) has been widely used as a test species owing to its responsiveness to nutrient deficiencies, rapid growth and general uniformity in seeds (O'Sullivan 1997). Moreover, other crop such as sweetpotato has been successfully used as test species in other nutrient omission studies (Dowling etal 1995, Alu et al 2012).

Nutrient deficiency in highly weathered soils of Samoa has been reported on crops other than sweetpotato. Soils were reported to have low CEC, deficient in calcium (Ca), potassium (K) and phosphorus (P) but contained toxic levels of manganese (Mn) (Asghar 1986, Bekker et al 1994, Bekker et al 1993). Nevertheless, the conditions of such soils were greatly improved when ameliorated with organic manure and coralline limestone were added resulting in improved growth of sweet corn (Hunter et al 1997, Bekker et al 1993) and peanut (Bekker et al 1993). Furthermore, crop performance was greatly improved under poor Oxisol conditions amended with green manure (Hunter et al 1995). Nutrient deficiency in a particular soil with reference to a specific species, however, may appear adequate in another species (O'Sullivan 1997) and ideally warrant investigation using sweetpotato.

There is limited information pertaining to nutrient deficiency in Oxisols of Samoa in relation to sweetpotato production. A study by Siose and Guinto (unpublished data) showed extremely poor growth of sweet potato grown on a Samoa Oxisol compared to silty clay and calcareous sandy soil types under a screen house conditions. It is, therefore, imperative to conduct a follow-up experiment and understand the cause of low productivity. Hence, this study was conducted to assist the government's efforts to promote the crop as an alternative food to taro thereby strengthening food security. With these initiatives, it is possible that future production will be enhanced by increasing the area planted with sweetpotato under Oxisols.

The objectives of this study are: a) to assess the effects of nutrient deficiencies on the vegetative growth of sweetpotato and b) identify the most limiting nutrient(s) to sweetpotato storage root yield.

\section{MATERIALS AND METHOD}

\section{Study location and soil preparation}

This study was conducted under a semi-protected screen house at the University of the South Pacific, School of Agriculture and Food Technology, Alafua Campus, Samoa. The screen house was enclosed with insect screening cloth on all sides with the top roof covered with clear transparent plastic. There were no built-in mechanisms for controlling and monitoring the inner conditions such as temperature and humidity of the 
so these are largely affected by the external weather conditions. The average monthly temperature and relative humidity recorded from the campus weather station is presented in Fig. 1. The experimental area is characterized of having a tropical climate with a yearly mean temperature and rainfall of $29^{\circ} \mathrm{C}$ and $3500 \mathrm{~mm}$, respectively. Samples of the identified Oxisol from Matafa'a village farm in Samoa were collected, homogenized and air dried at room temperature. Based on USDA classification, the soil was classified as an Oxisol of Haploperox Humic Great group and Subgroup respectively (Russell 1990). The properties of the soil are presented in Table 1.

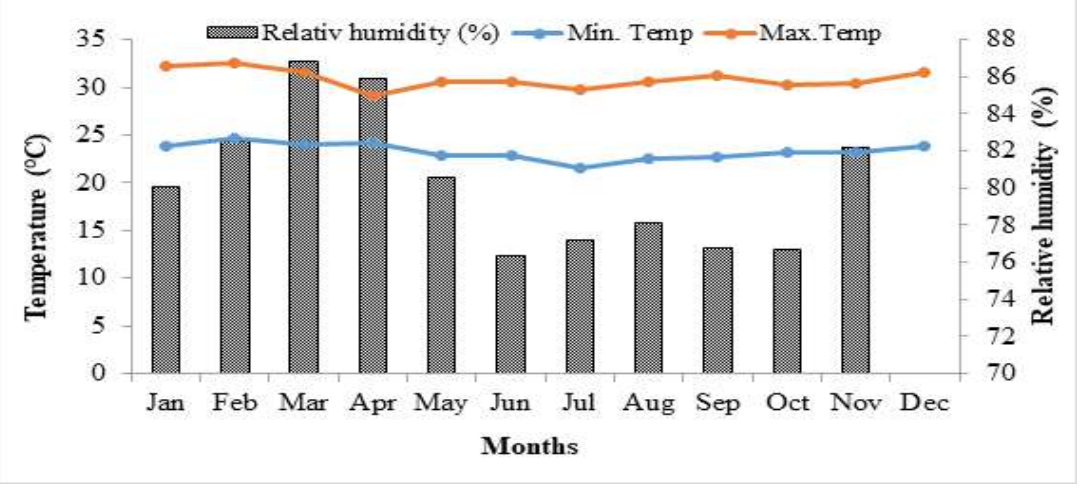

Figure 1. Average temperature and relative humidity recorded in Alafua campus, 2016. (Source: Samoa Meteorological Service).

Table 1. The characteristics of the soil

\begin{tabular}{|c|c|c|c|}
\hline Parameter & Value & Method & Reference \\
\hline Bulk density $\left(\mathrm{Mg} \mathrm{m}^{-3}\right)$ & 0.82 & Core sampler & \\
\hline Texture & & Pipette method & \multirow[t]{5}{*}{ Bouyoucos (1962) } \\
\hline Clay (\%) & 95 & & \\
\hline Silty (\%) & 2 & & \\
\hline Sand $(\%)$ & 3 & & \\
\hline Textural class & Clay & & \\
\hline $\mathrm{pH}$ & 4.77 & 1:5 (soil:water) & \\
\hline Organic C $(\% \mathrm{C})$ & 0.19 & $\begin{array}{l}\mathrm{K}_{2} \mathrm{Cr}_{2} \mathrm{O}_{7} \text { Wet } \\
\text { oxidation }\end{array}$ & Walkley Black (1934) \\
\hline Total N (\% N) & 0.018 & Kjeldhal & Walkley Black (1934) \\
\hline Available $\mathrm{P}\left(\mathrm{mg} \mathrm{kg}^{-1}\right)$ & 3.57 & $\mathrm{NaHCO}_{3}$ extraction & Olsen et al. (1954) \\
\hline $\operatorname{CEC}\left(\mathrm{cmol}(+) \mathrm{kg}^{-1}\right)$ & 32.1 & Index cation & $\begin{array}{c}\text { Daly et al. (1984; } \\
\text { Blakemore et al. (1987) }\end{array}$ \\
\hline Exchangeable cation $\left(\mathrm{cmol}(+) \mathrm{kg}^{-1}\right)$ & & $\mathrm{NH}_{4} \mathrm{OAc}$ & \multirow{4}{*}{$\begin{array}{c}\text { Daly et al. (1984; } \\
\text { Blakemore et al. (1987) }\end{array}$} \\
\hline $\mathrm{Ca}$ & 0.25 & & \\
\hline $\mathrm{Mg}$ & 0.82 & & \\
\hline $\mathrm{K}$ & 0.06 & & \\
\hline $\mathrm{Al}$ & 5.21 & Titrimetric & \multirow[t]{2}{*}{ Thomas (1982) } \\
\hline Exchangeable acidity $\left(\mathrm{cmol}(+) \mathrm{kg}^{-1}\right)$ & & Titrimetric & \\
\hline Micronutrients $\left(\mathrm{mg} \mathrm{kg}^{-1}\right)$ & & DTPA & \multirow[t]{5}{*}{ Lindsay and Norvell, (1978) } \\
\hline $\mathrm{Fe}$ & 7.64 & & \\
\hline $\mathrm{Mn}$ & 12.7 & & \\
\hline $\mathrm{Cu}$ & 0.104 & & \\
\hline $\mathrm{Zn}$ & 0.052 & & \\
\hline
\end{tabular}




\section{Preliminarytests}

According to Asher et al (2002), two preliminary tests were conducted in implementing this research. First, constructing a $\mathrm{pH}$ curve to determine the lime $\left(\mathrm{Ca}(\mathrm{OH})_{2}\right)$ rate required to raise the $\mathrm{pH}$ to 6.0 since the inherent soil $\mathrm{pH}$ was less than 5.2. Because calcium (Ca) was added via this lime, it was excluded from the nutrient solution stocks. The required $\mathrm{pH}$ was attained when lime was applied at the rate of $0.1 \mathrm{~g} / 20 \mathrm{~g}$ soil. Second, the determination of the optimum level of "ALL" nutrients required for maximum sweetpotato yield. The "ALL" comprised of nutrient solutions of nitrogen $(\mathrm{N}), \mathrm{P}, \mathrm{K}$, magnesium $(\mathrm{Mg})$, sulphur $(\mathrm{S})$, boron $(\mathrm{B})$, copper $(\mathrm{Cu})$, iron (Fe), Mn, molybdenum (Mo), nickel (Ni), and zinc ( $\mathrm{Zn}$ ) prepared (Table 2 ) and applied in increasing levels according to Asher et al (2002). The highest "ALL" level (i.e. $20 \mathrm{ml}$ of each nutrient solution) produced the highest storage root yield (Table 3) and therefore was used in the main omission trial.

Table 2. Application rate of nutrient based on Asher et al 2002.

\begin{tabular}{|c|c|c|c|c|}
\hline Element & $\begin{array}{c}\text { Application } \\
\text { rate of } \\
\text { element } \\
\left(\mathbf{k g ~ h a}^{-1}\right)\end{array}$ & Compound & $\begin{array}{c}\text { Rate of } \\
\text { application of } \\
\text { compound } \\
\left(\mathbf{k g ~ h a}^{-1}\right)\end{array}$ & $\begin{array}{c}\text { Concentration of } \\
\text { compound in } \\
\text { stock solution } \\
\text { (g salt L }\end{array}$ \\
\hline $\mathbf{N}$ & 100 & $\mathrm{NH}_{4} \mathrm{NO}_{3}$ & 286 & 104.02 \\
\hline $\mathbf{P}$ & 30 & $\mathrm{NaH}_{2} \mathrm{PO}_{4} \cdot 2 \mathrm{H}_{2} \mathrm{O}$ & 173 & 62.8 \\
\hline $\mathbf{K}$ & 80 & $\mathrm{KCl}$ & 161 & 58.6 \\
\hline $\mathbf{M g}$ & 30 & $\mathrm{MgCl}_{2} \cdot 6 \mathrm{H}_{2} \mathrm{O}$ & 250 & 91.0 \\
\hline $\mathbf{S}$ & 25 & $\mathrm{Na}_{2} \mathrm{SO}_{4}$ & 111 & 40.4 \\
\hline $\mathbf{F e}$ & 5 & $\mathrm{FeNaEDTA}_{4}$ & 100 & 36.4 \\
\hline $\mathbf{B}$ & 2 & $\mathrm{H}_{3} \mathrm{BO}_{3}$ & 11.4 & 4.14 \\
\hline $\mathbf{M n}$ & 5 & $\mathrm{MnCl}_{2} \cdot 4 \mathrm{H}_{2} \mathrm{O}$ & 16.4 & 5.96 \\
\hline $\mathbf{Z n}$ & 4 & $\mathrm{ZnCl}_{2}$ & 8.34 & 3.02 \\
\hline $\mathbf{C u}$ & 3 & $\mathrm{CuCl}_{2} \cdot 2 \mathrm{H}_{2} \mathrm{O}$ & 8.04 & 2.92 \\
\hline $\mathbf{M o}$ & 0.4 & $\left(\mathrm{NH}_{4}\right)_{6} \mathrm{Mo}_{7} \mathrm{O}_{24} .4 \mathrm{H}_{2} \mathrm{O}$ & 5.15 & 1.87 \\
\hline $\mathbf{N i}$ & 0.1 & $\mathrm{NiCl}_{2} \cdot 6 \mathrm{H}_{2} \mathrm{O}$ & 0.41 & 0.15 \\
\hline
\end{tabular}

Table 3 Storage root dry weight (g plant ${ }^{-1}$ ) obtained in the preliminary test

\begin{tabular}{|c|c|}
\hline Treatment & Mean \\
\hline -ALL & $3.02^{\mathrm{b}}$ \\
\hline ALL $\times \mathbf{0 . 5}$ & $3.02^{\mathrm{b}}$ \\
\hline ALL $\times 1.0$ & $3.76^{\mathrm{ab}}$ \\
\hline ALL $\times 2.0$ & $4.18^{\mathrm{ab}}$ \\
\hline ALL $\times 3.0$ & $3.71^{\mathrm{ab}}$ \\
\hline ALL $\times 4.0$ & $6.61^{\mathrm{a}}$ \\
\hline
\end{tabular}

* 1 indicate $5 \mathrm{ml}$ of each solution presented in Table 2 applied in $6 \mathrm{~kg}$ soil. Means with similar letters are not significantly different at $P=0.05$ according to Tukeys's HSD test. 


\section{The main nutrientomission trial}

Six kg of air-dried soil (sieved $<1 \mathrm{~cm}^{2}$ ) that has been mixed thoroughly with lime was placed into each pot lined with plastics to prevent water loss through draining of and nutrient leaching. The pots were equilibrated for 7 days before the applications of the nutrient solutions (treatments). The treatments consist of "ALL" and the subsequent 12 treatments made by excluding one nutrient consecutively from the ALL combination. The schematized quantities of each nutrient solution added/omitted in each treatment are presented in Table 4. Each nutrient solution was evenly sprinkled on the soil and thoroughly mixed by hand in a wide-mouth plastic basin (Fig. 2) before the soil was poured back into respective pots. To prevent contamination from mixing, three basins were used alternately with thorough cleaning with distilled water and drying prior to the succeeding mixing. To minimize dust contamination during the equilibration period ( 7 days), the soil was again covered with the overlapping lining plastic (Fig. 3). Pots were arranged in a randomized complete block design. All except the "ALL" treatment (replicated 6 times) were replicated 4 times.

Table 4. Scheme for adding (20) and omitting (0) of stock solution in $\mathrm{ml} \mathrm{pot}^{-1}$ of the omission trial.

\begin{tabular}{|c|c|c|c|c|c|c|c|c|c|c|c|c|}
\hline \multicolumn{13}{|c|}{ Solution ID } \\
\hline Treatment & $-\mathrm{N}$ & $-P$ & $-K$ & $-S$ & $-\mathrm{Mg}$ & $-\mathrm{Fe}$ & $-B$ & $-Z n$ & $-M n$ & $-\mathrm{Cu}$ & -Mo & $-\mathrm{Ni}$ \\
\hline All & 20 & 20 & 20 & 20 & 20 & 20 & 20 & 20 & 20 & 20 & 20 & 20 \\
\hline$-\mathrm{N}$ & 0 & 20 & 20 & 20 & 20 & 20 & 20 & 20 & 20 & 20 & 20 & 20 \\
\hline$-\mathbf{P}$ & 20 & 0 & 20 & 20 & 20 & 20 & 20 & 20 & 20 & 20 & 20 & 20 \\
\hline$-K$ & 20 & 20 & 0 & 20 & 20 & 20 & 20 & 20 & 20 & 20 & 20 & 20 \\
\hline$-\mathrm{S}$ & 20 & 20 & 20 & 0 & 20 & 20 & 20 & 20 & 20 & 20 & 20 & 20 \\
\hline -Mg & 20 & 20 & 20 & 20 & 0 & 20 & 20 & 20 & 20 & 20 & 20 & 20 \\
\hline$-\mathrm{Fe}$ & 20 & 20 & 20 & 20 & 20 & 0 & 20 & 20 & 20 & 20 & 20 & 20 \\
\hline -B & 20 & 20 & 20 & 20 & 20 & 20 & 0 & 20 & 20 & 20 & 20 & 20 \\
\hline$-\mathbf{Z n}$ & 20 & 20 & 20 & 20 & 20 & 20 & 20 & 0 & 20 & 20 & 20 & 20 \\
\hline -Mn & 20 & 20 & 20 & 20 & 20 & 20 & 20 & 20 & 0 & 20 & 20 & 20 \\
\hline$-\mathrm{Cu}$ & 20 & 20 & 20 & 20 & 20 & 20 & 20 & 20 & 20 & 0 & 20 & 20 \\
\hline -Mo & 20 & 20 & 20 & 20 & 20 & 20 & 20 & 20 & 20 & 20 & 0 & 20 \\
\hline$-\mathrm{Ni}$ & 20 & 20 & 20 & 20 & 20 & 20 & 20 & 20 & 20 & 20 & 20 & 0 \\
\hline
\end{tabular}

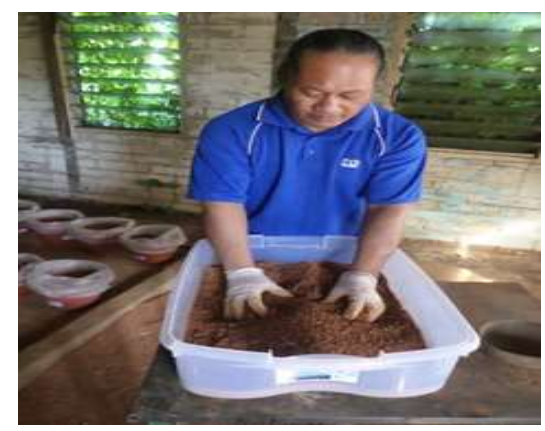

Figure 2. Manual mixing of the nutrient solution with soil

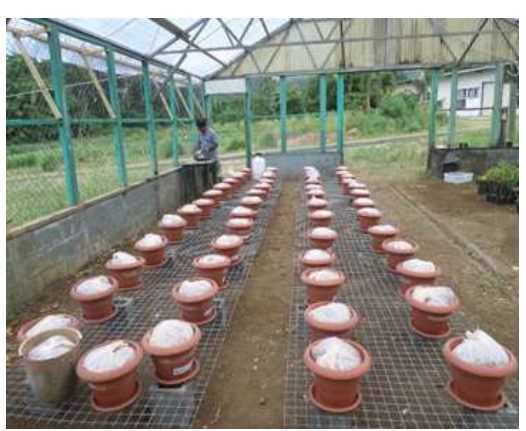

Figure 3. Pots covered to avoid dust contamination during equilibration period 


\section{Plantculture}

Defoliated fresh vine tips of sweetpotato variety IB/PH/03 of $30 \mathrm{~cm}$ were planted singly in each pot with 2 nodes buried beneath the soil after watered to field capacity with distilled water. Planting was done in $7^{\text {th }} \mathrm{July}$ 2016. Subsequent irrigation schemes to achieve $80 \%$ field capacity was routinely carried out when required. Plants were allowed to grow for 20 weeks.

\section{Data collection and analysis}

Vine length, number of leaves and branches were measured at 4,12 and 20 weeks after planting (WAP) using measuring tape meter and counting, respectively, while the leaf chlorophyll was quantified only during harvest using a Konica Minolta SPAD-502 Plus chlorophyll meter. Also at harvest, fresh and dry weight of vines and roots were recorded. Number of roots was also recorded. Data recorded were subjected to analyses of variance using SPSS and mean difference were separated using the least significant difference (LSD) at $\alpha=0.05$.

\section{RESULTS AND DISCUSSION}

\section{Soil characteristics}

The initial soil characteristics are presented in Table 1. Textural analysis indicated the soil has high clay content. Chemical analysis indicated an inherently acidic soil typical of an Oxisol with very low levels of nutrient elements. The presence of high exchangeable acidity and aluminium level presents a major threat to crop production. In fact according to Thomas (1982), exchangeable acidity values greater than 1 $\mathrm{cmol}(+) \mathrm{kg}^{-1}$ soil is a potential threat to crop growth. The acidity of the soil used in this study was $5.27 \mathrm{cmol}(+) \mathrm{kg}^{-1}$, which is 5 -fold higher than the threshold reported by Thomas (1982). About 98\% of this acidity is comprised of exchangeable Al. Micronutrients are also scarcely available. Without fertilizer supplements, poor crop growth is expected under this soil.

\section{Vegetative growth}

The distinct effects of nutrient omission trials from the Oxisol on sweetpotato vine length was recorded at 20 WAP (Fig. 4). At this stage, vine length was significantly shorter only when $\mathrm{P}$ was not applied. Consequently, the P-deficient plant produced significantly fewer number of leaves (Fig. 5) and vines (Fig. 6). Although the vine length was not affected by $\mathrm{N}$ deficiency, Figures 5 and 6 showed decline number of leaves and vines at harvest, respectively when soil is $\mathrm{N}$-deficient. The omission of 
of $\mathrm{N}$ and $\mathrm{P}$ resulted in significantly lowest chlorophyll content (Fig. 7) and decreased aboveground biomass at harvest (Fig. 8) compared to all the other treatments.

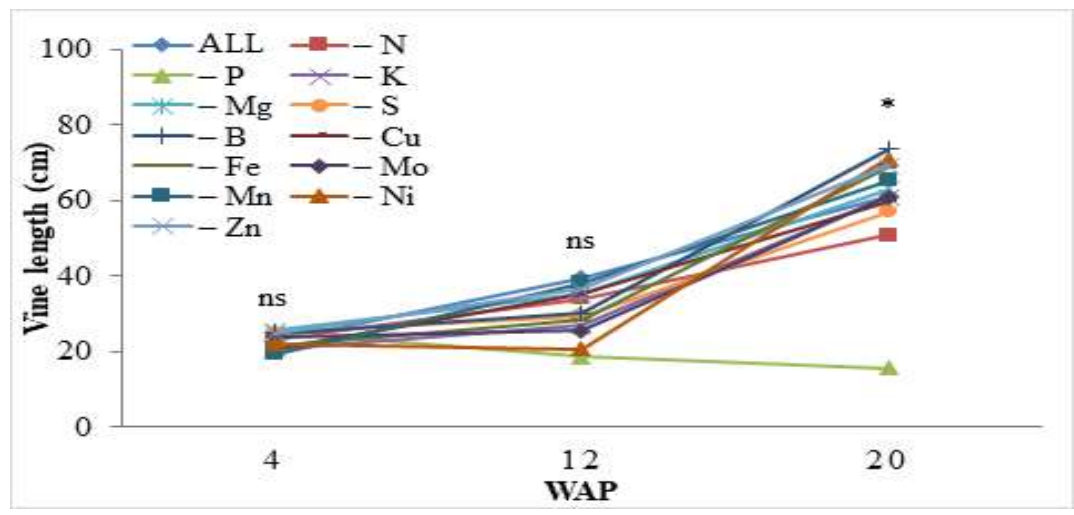

Figure 4. Vine growth in sweetpotato as affected by the nutrient omission technique. ns, * denotes not significant and significant, respectively at $P=0.05$.

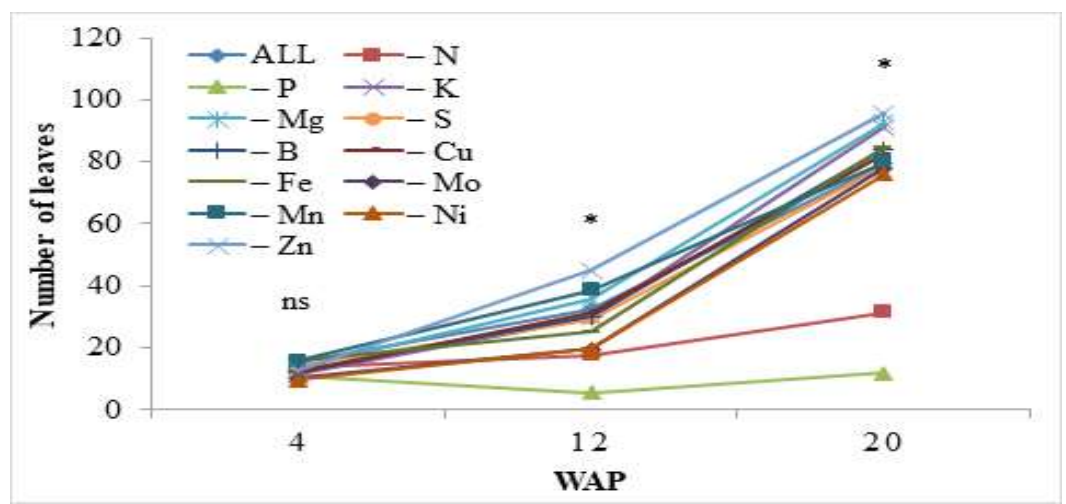

Figure 5. Number of sweetpotato leaves as affected by nutrient omission method. $\mathrm{ns},{ }^{*}$ denotes not significant and significant, respectively at $P=0.05$.

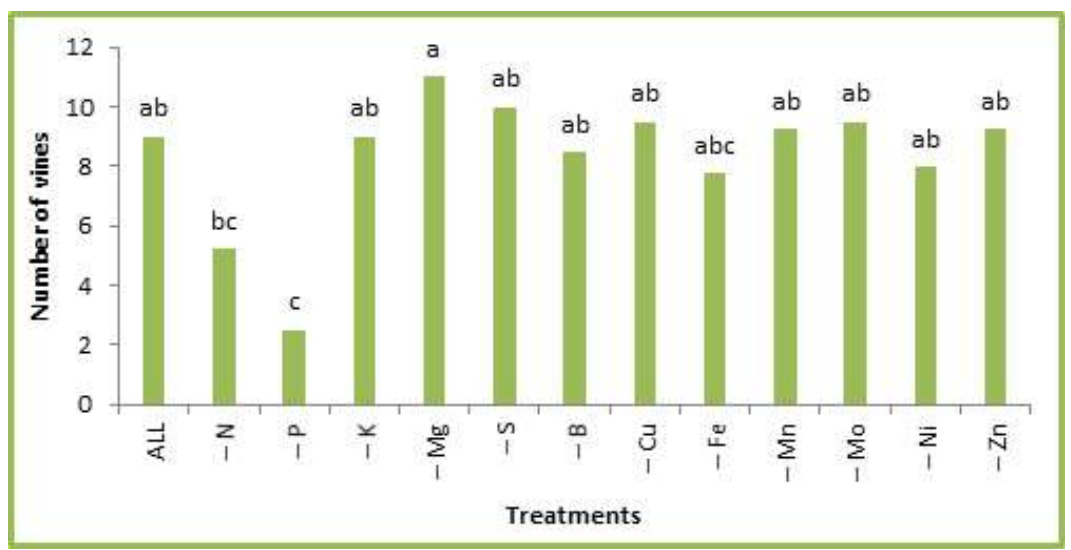

Figure 6. Number of sweetpotato vines in response to treatment at 20 WAP. Similar letters above bars shows insignificant difference between treatment means at $P=0.05$. 
The vegetative performance of sweetpotato was adversely affected without $\mathrm{P}$, and to a lesser extent, $\mathrm{N}$. Details of $\mathrm{P}$ and $\mathrm{N}$ functions in plant nutrition are recorded in Hawkesford et al (2012) and Baset Mia, (2015). Phosphorus is vital to most physiological processes occurring in plant, thus its deficiency will greatly affect these processes such as photosynthesis. Consequently, the following can take place under P deficiency conditions: One of the striking effects is the reduced number of leaves produced in plants (Armstrong 1999, Lynch et al 1991) which is clearly demonstrated in Figure 5. Reduced leaf expansion is also a common symptom (Fredeen et al 1989, Fageria et al 2003) was notable throughout the entire experiment duration, although this was not quantified. Reduced cell sizes is also a resulted from $P$ deficiency (Baset Mia 2015) which the stunted plant growth (Fig. 4) may have been attributed to. According to Baset Mia (2015), $\mathrm{P}$ deficiency does not affect chlorophyll content, but impairs the photosynthetic activities in leaf. However, the obtained result reveals that limited supply of P reduced chlorophyll content (SPAD) significantly (Fig. 7). Positive significant correlation between this and other measured vegetative parameters (Table 5) signifies the unassailable nutritional role of $\mathrm{P}$ in sweetpotato vegetative growth.

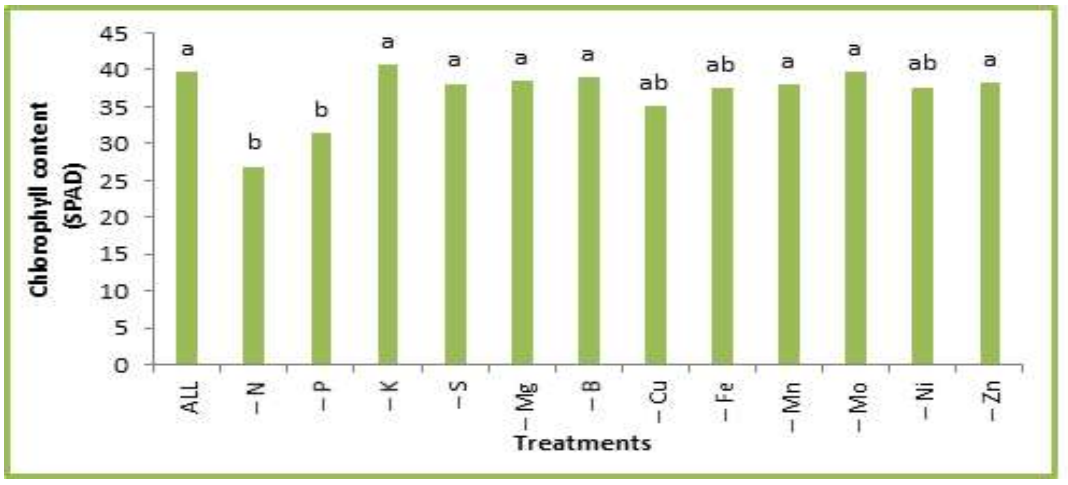

Figure 7. Chlorophyll content of sweetpotato leaf measured at 20 WAP. Similar letters above bars shows insignificant difference between treatment means at $P=0.05$.

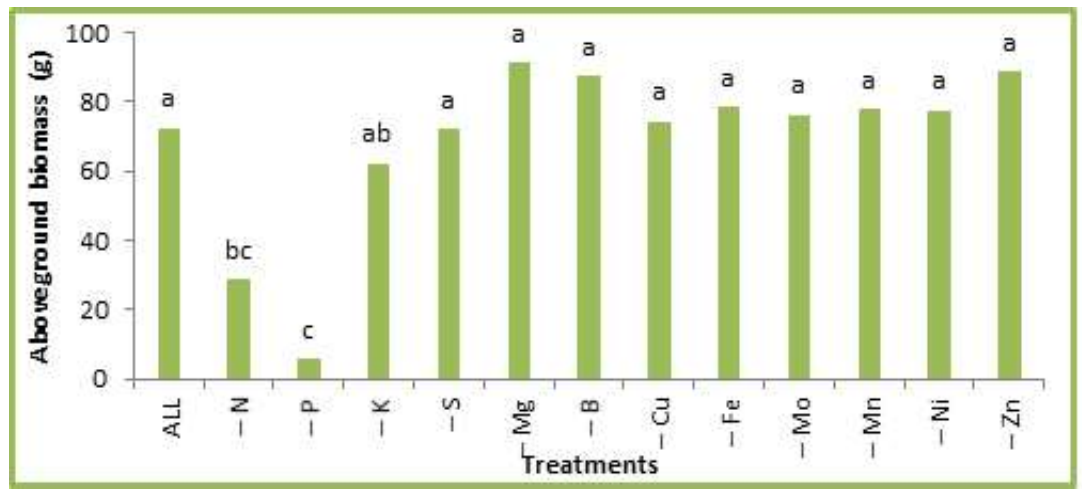

Figure 8. Sweetpotato aboveground fresh weight at 20 WAP as affected by treatments. Similar letters above bars shows insignificant difference between treatment means at $P=0.05$. 
Table 5. Correlation coefficients among vegetative parameters measured at harvest

\begin{tabular}{|l|l|l|l|l|}
\hline & $\begin{array}{l}\text { Chlorophyll } \\
\text { content }\end{array}$ & Vine length & $\begin{array}{l}\text { Number } \\
\text { of vines }\end{array}$ & $\begin{array}{l}\text { Number } \\
\text { of leaves }\end{array}$ \\
\hline Chlorophyll & 1 & $0.305^{*}$ & $0.376^{* *}$ & $0.377^{* *}$ \\
\hline Vine length & & 1 & $0.578^{* *}$ & $0.641^{* *}$ \\
\hline Number of vines & & & 1 & $0.832^{* *}$ \\
\hline Number of leaves & & & & 1 \\
\hline
\end{tabular}

*, **; significant at $P=0.05$ and $P=0.01$ respectively, $\mathrm{n}=54$.

Nitrogen is an intrinsic constituent of chlorophyll that in the absence of this element will drastically affect the photosynthesis process in crops. General yellowing of leaves indicates $\mathrm{N}$ deficiency in plants which is reflected by the significantly lowest SPAD at the $-\mathrm{N}$ treatment (Fig. 7). Inhibited photosynthetic rate has been attributed to the accumulated sugar due to poor utilization of sugar for $\mathrm{N}$ assimilation and growth under $\mathrm{N}$ deficiency conditions (Paul \& Driscoll 1997). This possibly explain the comparative poor sweetpotato vegetative performance in $\mathrm{N}$-deficient soil beside the -P treatment (Figures 5-8).

Macronutrients literally means nutrient elements that plant requires in relatively large quantities. Figure 5 demonstrated the irreplaceable physiological role of particularly $\mathrm{N}$ and $\mathrm{P}$ when undersupplied and resulted in drastic decrease in number of leaves. Omission of $\mathrm{K}, \mathrm{Mg}$, and $\mathrm{S}$ was comparatively less effective. In fact, when the soil is Mg-deficient, sweetpotato scored the highest number of leaves although this was not significantly differed from all except $-\mathrm{N}$ and -P treatments (Fig. 5). Even the vine biomass was highest when soil is made Mg deficient (Fig. 8). However, this is rather blurry because impairment of photosynthesis usually occurs when $\mathrm{Mg}$, a central molecule in a chlorophyll structure is inadequately supplied (Hawkesford et al 2012). The effect of micronutrients is analogous to the "ALL" treatment inferring growth is unaffected when omitted.

Under silty clay and calcareous sandy soils of Samoa, the same variety produced comparatively greater vegetative parts (vine length, number of vines and leaf number per plant) compared to this Oxisol (Siose and Guinto, unpublished data), even the results obtained data in this study. This implied that the crop's growth potential is still limited at the implemented dosage and is most likely to improve at higher levels.

\section{Storage rootyield}

Table 6 shows the storage root yield 20 WAP in response to the treatments. Yield was greatly and significantly reduced only when P was not applied. The omission of $P$ resulted in yield reduction by about sixteenfold in relation to the "ALL" treatment. Though the $-\mathrm{N}$ and $-\mathrm{K}$ treatments 
were recorded significantly higher and comparable to the "ALL" treatment, the yield difference between the former and the latter confirmed the important role these macronutrients play in the storage root production. These macronutrients ( $\mathrm{N}$ and $\mathrm{P}$ ) are critical nutrients for sweetpotato production (Njoku et al 2001), however, the comparatively higher yield of sweetpotato than that of $-\mathrm{P}$ suggested of $\mathrm{P}$ being the most critical nutrient in this Oxisol. Omitting other macronutrients and all the micronutrients did not affect root yield. The number of storage roots was recorded inferiorly at the $-\mathrm{P}$ treatment but comparable to all other treatments except the $-\mathrm{Mn}$ treatment. With regards to dry matter percentage, all except-P revealed similar results.

Table 6. Storage root yield after harvest (20 WAP)

\begin{tabular}{|l|c|c|c|}
\hline Treatments & Root fresh weight (g) & Number of roots & DM (\%) \\
\hline $\mathbf{A L L}$ & $135.0 \mathrm{a}$ & $3.33 \mathrm{ab}$ & $21.0 \mathrm{a}$ \\
\hline$-\mathbf{N}$ & $95.5 \mathrm{a}$ & $3.50 \mathrm{ab}$ & $20.4 \mathrm{a}$ \\
\hline$-\mathbf{P}$ & $8.5 \mathrm{~b}$ & $1.75 \mathrm{~b}$ & $11.9 \mathrm{~b}$ \\
\hline$-\mathbf{K}$ & $81.8 \mathrm{a}$ & $2.75 \mathrm{ab}$ & $25.8 \mathrm{a}$ \\
\hline$-\mathbf{M g}$ & $131.0 \mathrm{a}$ & $3.25 \mathrm{ab}$ & $21.8 \mathrm{a}$ \\
\hline$-\mathbf{S}$ & $107.8 \mathrm{a}$ & $2.75 \mathrm{ab}$ & $21.5 \mathrm{a}$ \\
\hline$-\mathbf{B}$ & $104.5 \mathrm{a}$ & $3.25 \mathrm{ab}$ & $21.3 \mathrm{a}$ \\
\hline$-\mathbf{C u}$ & $141.0 \mathrm{a}$ & $3.50 \mathrm{ab}$ & $20.9 \mathrm{a}$ \\
\hline$-\mathbf{F e}$ & $114.0 \mathrm{a}$ & $4.00 \mathrm{ab}$ & $21.6 \mathrm{a}$ \\
\hline$-\mathbf{M o}$ & $98.3 \mathrm{a}$ & $3.25 \mathrm{ab}$ & $20.6 \mathrm{a}$ \\
\hline$-\mathbf{M n}$ & $119.8 \mathrm{a}$ & $4.50 \mathrm{ab}$ & $20.7 \mathrm{a}$ \\
\hline$-\mathbf{N i}$ & $105.3 \mathrm{a}$ & $3.50 \mathrm{ab}$ & $19.9 \mathrm{a}$ \\
\hline$-\mathbf{Z n}$ & $133.0 \mathrm{a}$ & $3.25 \mathrm{ab}$ & $21.9 \mathrm{a}$ \\
\hline
\end{tabular}

Within a column, means with similar letters are not significantly different at $P=0.05$.

The results of this study strongly indicated the important role of $\mathrm{P}$ in storage root production in sweetpotato under Oxisol condition. Though inherent nutrients content are deemed low to very low (Table 1) according to ratings by Blakemore et al (1987), the most injurious effect is distinctively pronounced when $\mathrm{P}$ is made deficient. In fact, the absence of $\mathrm{P}$ will prevent the plant to achieve maturity.

Phosphorus's function as an essential plant nutrient cannot be replaced by any other nutrient. Maximum plant potential thus cannot be fully attained when $P$ is supplied inadequately (Fageria \& Gheyi 1999). Under field conditions, declined yield of sweetpotato has been attributed to P-deficiency (Issaka et al 2014, Dumbuya et al 2016) to adduce the importance role of P in root yield. The role of $\mathrm{P}$ in regulating many functions pertaining to root performance reviewed comprehensively by Fagaria (2013) further supports the poor yield in sweetpotato when grown in P-impoverished soil. These findings were supported by the results obtained by Tulin and co-workers in cabbage grown in an Andisol in the Philippines (Tulin etal 2013). 
Significant and lowest percentage root dry weight was noted in -P treatment relative to the "ALL" treatment (Fig. 9). It is worth noting that relative to "ALL", reduced yield in response to the omission of $\mathrm{N}, \mathrm{K}, \mathrm{S}, \mathrm{B}, \mathrm{Fe}$, $\mathrm{Mn}, \mathrm{Mo}$, and Ni ranging from 68 to $86 \%$ indicates the soil is deficient in these nutrients although the yield difference is insignificant. However, according to the 'law of the minimum', unless $\mathrm{P}$ is optimally supplied, root yield in sweetpotato will not respond to further additions of the above nutrients. Higher yield is obtained where $\mathrm{Cu}$ and $\mathrm{Zn}$ were omitted indicated too high or potentially toxic levels of these micronutrients when applied at this dosage. The omission of $\mathrm{Mg}$ resulted in root yield equivalent to that at of "ALL" implies that whether or not it is added, yield is unaffected.

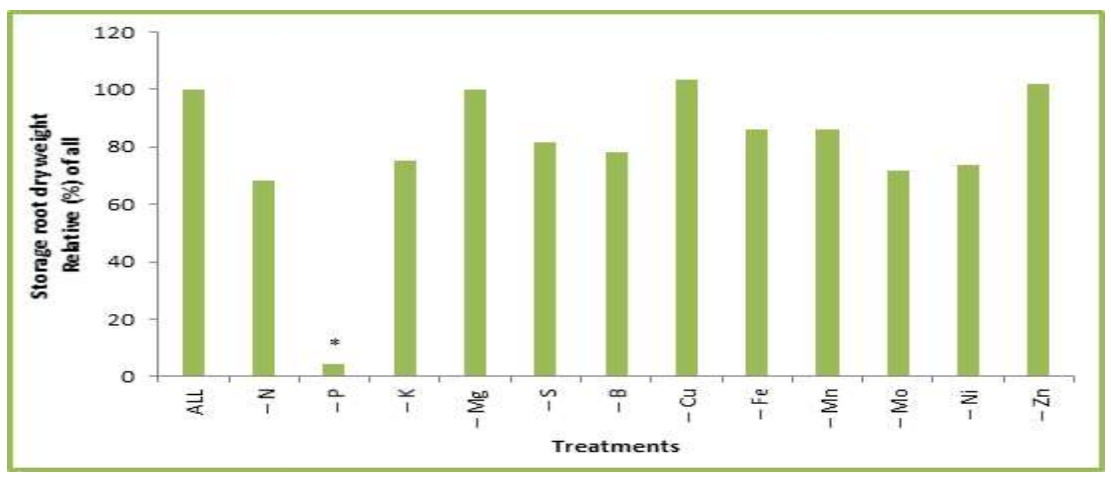

Figure 9. Storage root dry weight relative to the "ALL" treatment (\%). *, significantly less than the "ALL" treatment.

The vegetative parameters at 12 and 20 WAP showed positive and significant association with the storage root yield (Table 7). This indicated that higher vegetative yield will produce higher storage root yield with number of leaves having the greater effect due to stronger association at harvest. The reduced fixation of carbon and assimilation in crop due to $\mathrm{P}$ deficiency (Freeden et al 1990, Halsted \& Lynch 1996) is clearly reflected in the significantly lower yield due to reduced number of leaves at the $-\mathrm{P}$ treatment.

Table 7. Correlation coefficient between storage root and vegetative parameters recorded at 12 and 20 weeks after planting (WAP)

\begin{tabular}{|l|c|c|}
\hline & \multicolumn{2}{|c|}{ Storage root yield } \\
\hline & $\mathbf{1 2}$ WAP & $\mathbf{2 0}$ WAP \\
\hline Vine length & $0.658^{* *}$ & $0.449^{* *}$ \\
\hline Number of vines & $0.562^{* *}$ & $0.481^{* *}$ \\
\hline Number of leaves & $0.534^{* *}$ & $0.612^{* *}$ \\
\hline
\end{tabular}

\section{Drymatter partitioning}

Dry matter partitioned to root and stem at harvest is illustrated in Figure 10. Although the vegetative growth exhibited active growth at 
harvest (Figures 3 and 4), more dry matter was translocated in roots. This is normally the case in sweetpotato when assimilates should be consigned to the root more than to the vegetative part (van de Fliert \& Braun 1999). But under nutrient deficient conditions, a model by Thornley (1972) suggests a favored partitioning of photosynthate to the roots (phloem transport) is due to increased carbon concentration, while sufficient supply of nutrients for e.g. $\mathrm{N}$ will increase $\mathrm{N}$ concentration leading to higher DM partitioning to shoot (xylem transport). This is evidently shown by a remarkably higher DM partitioned to root when $\mathrm{N}$ is made deficient in relation to the "ALL" treatment. The effect of omitting other nutrients did result in higher root DM to roots but comparatively lower than "ALL" treatment. The $-\mathrm{P}$ treatment had the least percentage DM partitioned to root, but scored the highest percentage DM partitioned to the vegetative part.

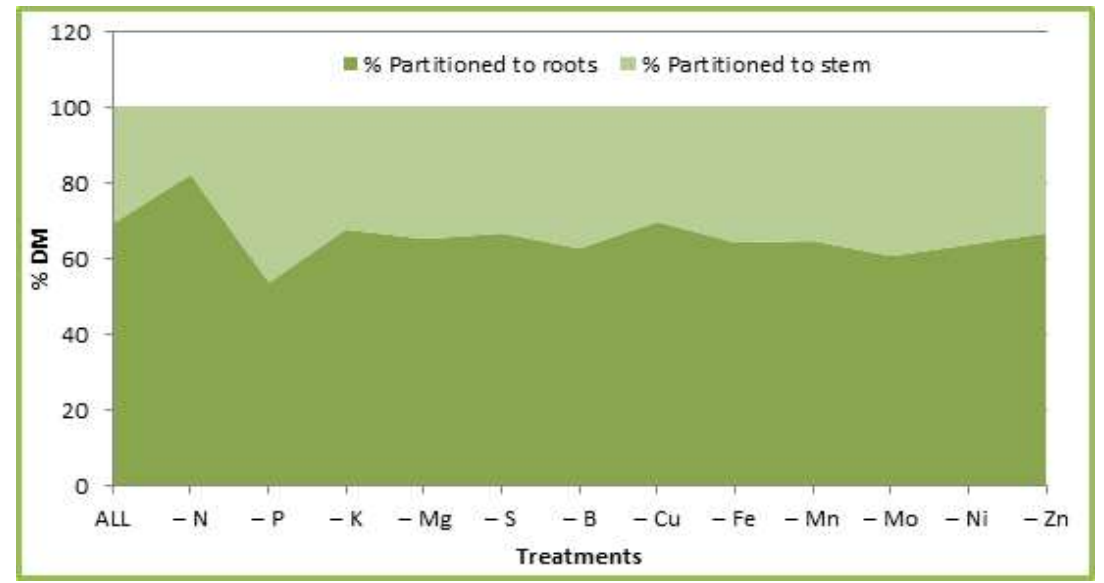

Figure 10. Percent of dry matter partitioned to roots and stem as influenced by nutrientomission.

\section{CONCLUSION}

$\mathrm{P}$ is the most limiting factor to sweetpotato vine growth and leaf production during its growth cycle, as well as the chlorophyll content, aboveground biomass and the root yield at harvest in an Oxisol in Samoa. Based on root dry weight, yield was reduced in response to $\mathrm{N}, \mathrm{K}, \mathrm{S}, \mathrm{B}, \mathrm{Fe}, \mathrm{Mn}$, Mo and Ni deficiencies in relation to the "ALL" treatment. However, their impact on sweetpotato yield is relatively insignificant. Unless P deficiency is fixed, it remains the most limiting nutrient factor. A field trial is necessary to verify the results obtained in this study before making a concrete conclusion. 


\section{REFERENCES}

ALU, K., RAJASHEKHAR RAO, B. K. and BAILEY, J. S. 2012. Effects of sulphur fertilisation on growth response of sweetpotato vines. Niugini Agrisaiens, 4: 52-57.

ARMSTRONG, D. L. (Ed). 1999. Functions of P in plants, Better Crops with Plant Food, 83(1): 6-7.

ASGHAR, M. 1986. The nature and properties of Western Samoa soils. In: Asghar, M. Davidson, T. J. and Morrison, R. J. (eds.). Proceedings of the XVth International Forum on Soil Taxonomy and Agrotechnology Transfer. IRETA/USP. Apia, Western Samoa. pp. 366-375.

ASHER, C., GRUNDON, N. and MENZIES, N. 2002. How to unravel and solve soil fertility problems, ACIAR Monograph No. 83, 139p.

BASET MIA, M. A. 2015. Nutrition of crop plants - Plant science, research and practices. Nova Science Publisher, Inc. NY.pp. 69-74.

BEKKER, A. W., CHASE, R. G. and HUE, N. V. 1993. Effects of coralline lime on nutrient uptake and yield of field-grown sweet corn and peanuts in Oxidic soils of Western Samoa. Fertiliser Research, 36: 211-219.

BEKKER, A. W. HUE, N. V., YAPPA, L. G. G. and CHASE, R. G. 1994. Peanut growth as affected by liming, Ca-Mn interactions and $\mathrm{Cu} \& \mathrm{Zn}$ applications to acid Samoa soils. Plant and Soil, 164: 203-211.

BLAKEMORE, L.C., SEARLE, P.L. and DALY, B.K. 1987. Methods of Chemical Analysis of Soils. New Zealand Soil Bureau Scientific Report 80. pp: 103.

BRADY, N. C. and WEIL, R. R. 2010. Elements of the nature and properties of soil. $3^{\text {rd }}$ Edn. Pearson Education, Inc., Prentice Hall, Upper Saddle River, NJ, pp. 82-83.

BOUYOUCOS, G.J. 1962. Hydrometer method improved for making particle size analysis of soils. Agronomy Journal 54, 464-465.

DALY, B.K., MANU, V.T. and HALAVATAU, S.M. 1984. Soil and plant analysis methods for use at the Agricultural Research Station, Vaini, Tonga. New Zealand Soil Bureau Laboratory Report AN2.

DOWLING, A. J., BLAMEY, F. P. C. and HOA, T. 1995. Limitations to sweetpotato growth in small volumes of soil imposed by water and nutrient stress, acidity and salinity. Papua New Guinea Journal of Agriculture, Forestry and Fisheries, 38(1): 3-10.

DUMBUYA, G., SARKODIE-ADDO, J., DARAMY, M. A. and JALLOH, M. 2016. Growth and yield of sweetpotato to different tillage methods and phosphorus fertiliser rates in Ghana. Journal of Experimental Biology and Agricultural Science, 4(5): 475-483.

FAGERIA, N. K. 2013. The role of plant roots in crop production. CRC Press, NY.p.315-321.

FAGERIA, N. K. and GHEYI, H. R. 1999. Efficient crop production. Campina Grande, Paraiba, Brazil, Federal University of Paraiba.

FAGERIA, N, K., SLATON, N. A. and BALIGAR, V. C. 2003. Nutrient management for improving lowland rice productivity and sustainability. Advance Agronomy, 80: 63-153. 
FAGERIA, N. K. and STONE, L. F. 1999. Acidity Management of Cerrado and Varzea Soils of Brazil. Santo Anto^ nio de Goia's, Brazil.

FOTH, H. D. 1990. Fundamentals of soil science. $8^{\text {th }}$ Edn. John Wiley \& Sons, NY, USA. pp. 305.

FREDEEN, A. L., RAO, I. M and TERRY, N. 1989. Influence of phosphorus nutrition on growth and carbon partition in Glycine max. Plant physiology, 89: 225-230.

FREDEEN, A. L., RAAB, T. K., RAO, I. M. and TERRY, N. 1990. Effects of phosphorus on photosynthesis in Glyne max L. Merr. Planta 181: 399405.

GEORGE, E., HORST, W. J. and NEUMANN, E. 2012. Adaptation of plants to adverse chemical soils conditions. In: Petra Marshner (Ed). Marschner's mineral nutrition of higher plants. $3^{\text {rd }}$ Edn, Academic Press, USA. pp. 409-472.

HALSTED, M. and LYNCH, J. 1996. Phosphorus responses of $\mathrm{C}_{3}$ and $\mathrm{C}_{4}$ species. Journal of Experimental Botany, 47: 497-505.

HUNTER, D. J., YAPPA, L. G. G. and HUE, N. V. 1997. Effects of green manure and coral lime on corn growth and chemical properties of an acid Oxisol in Western Samoa. Biology, Fertiliser and Soils, 24: 266-273.

HUNTER, D. J., YAPPA, L. G. G., HUE, N. V. and M. EAQUB. 1995. Comparative effects of green manure and lime on the growth of sweet corn (Zea mays), and chemical properties of an acid Oxisol in Western Samoa. Communication in Soil Science and Plant Analysis, 26(3 \& 4): 375-388.

HAWKESFORD, M., HORST, W., KICHEY, T., LAMBERS, H., SCHJOERRING, J., MOLLER, I. S. and WHITE, P. 2012. Functions of macronutrients. In: P. Marschner (ed), Marschner's mineral nutrition of higher plants, $3^{\text {rd }}$ Edn. Academic Press, USA. pp. 135-190.

ISSAKA, R. N, BURI, M. M., ENNIN, S. A. and GLOVER-AMENGOR, M. 2014. Effect of mineral fertilisation on sweetpotato (Ipomoea batatas (L.)) yield in the Sudan savannah agro-ecological zone of Ghana, Internation Journal of Agriculture Innovations and Research, 2(5): 831-834.

LEONARD, O. A., ANDERSON, W. S. and GIEGER, M. 1948. Effect of nutrient level on the growth and chemical composition of sweetpotatoes in sand culture. Plant Physiology, 23: 223-235.

LINDSAY, W.L. and NORVELL, W.A. 1978. Development of a DTPA soil test for zinc, iron, manganese, and copper. Soil Science Society of America Journal 42, 421-428.

LYNCH, J., LAUCHLI, A. and EPSTEIN, E. 1991. Vegetative growth of the common bean in response to phosphorus nutrition. Crop science, 31: 380-387.

MOSSOR-PIETRASZEWSKA, T. 2001. Effect of aluminium on plant growth and metabolism. Acta Biochimica Polonica, 48(3): 673-686.

NJOKU, J. C., OKPARA, D. A. and ASIEGBU, J. E. 2001. Growth and yield responses of sweetpotato to inorganic nitrogen and potassium in a tropical ultisol. Nigerian Agricultural Journal 32: 30-40. 
O'SULLIVAN, J. N., ASHER, C. J. and BLAMEY, F. P. C. 1997. Nutrient disorders of sweet potato. ACIAR Monograph No 48,136p.

PAUL, M. J. and DRISCOLL, S. P. 1997. Sugar repression of photosynthesis: the role of carbohydrates in signalling nitrogen deficiency through source:sink imbalance. Plant Cell Environment, 20: 110-116. Cited in Engel, C. Kirkby, E and White P. Mineral nutrition, yield and source-sink relationships, In: P. Marschner (ed), Marschner's mineral nutrition of higher plants, $3^{\text {rd }}$ Edn. Academic Press, USA. pp.85-134.

PLIETH, C. SATTEMACHER, B., HANSEN, U. P. and KNIGHT, M. R. 1999. Low pH-mediated elevations in cytosolic calcium are inhibited by aluminium: a potential mechanism for aluminium toxicity. Plant Journal, 18: 643-650.

POIHEGA, J. M. A., YAPPA, L. G. G. and ASHER, C. J. 1996. The use of pot experiments to assess the chemical fertility of selected soils in Western Samoa. In: Craswell, E. T., Asher, C. J. and O'Sullivan, J. N. (eds) Mineral Nutrient Disorders of Root Crops in the Pacific, Proceedings of a workshop, Nuku'alofa, Kingdom of Tonga, 17-20 April, 1995.

RENGEL, Z. AND ROBINSON, D. L. 1989. Aluminium effects on growth and macronutrient uptake by annual ryegrass. Agronomy Journal, 81: 208215.

RUSSEL, P (ed). 1990. Land resource planning study Western Samoa. Asian Development Bank TA No. 1065 - Sam Final Report. Lower Hutt, New Zealand. 147p.

THORNLEY, J. H. M. 1972. A balanced quantitative model for root:shoot ratio in vegetative plants. Annals of Botany, 36: 431-441.

THOMAS, G. W. 1982. Exchangeable cations. In: Methods of Soil Analysis. Part 2. Page, A. L. (Ed). American Society of Agronomy and Soil Science Society of America. $1159 \mathrm{p}$.

TULIN, A.B., RALLOS, R.V., RAÑISES, M. B., and DORAHY, C.H. 2013. Increasing cabbage production through NPK application in Cabintan, Ormoc City, Leyte, Philippines. Annals of Tropical Research. Volume 35 No. 1, pp 118-130.

SANCHEZ, P. A. and SALINAS, J. G. 1981. Low-input technology for managing Oxisols and Ultisols in tropical America. Advances in Agronomy 34, 280-406.

van de FLIERT., E and BRAUN, A. 1999. Farmer field school for integrated crop management of sweetpotato. Field guides and technical manual. International Potato Center. Lima, Peru. 266 p.

VITOUSEK, P. M. and SANDFORD JR., R. L. 1986. Nutrient cycling in moist tropical forest. Annual Review of Ecology and Systematics. 17: 137-167.

WALKLEY, A. and BLAKE, I.A. 1934. An examination of the Degtjareff method for determining organic matter, and a proposed modification of the chromic acid titration method. Soil Science 37, 29-38. 